\title{
The Use of Team Word Webbing in Writing Skill for EFL Students
}

\author{
Ari Prasetyaningrum \\ Hamzanwadi University, Indonesia \\ Correspondence: Ari Prasetyaningrum, Indonesia. e-mail: prasetya18@yahoo.com \\ Received: July 31, 2018 \\ Accepted: September 01, 2018 Online Published: September 15, 2018 \\ doi: $10.29408 /$ veles.v2i2.843.g584 \\ URL: http://dx.doi.org/10.29408/veles.v2i2.843.g584
}

\begin{abstract}
The purposes of this study were examining whether the use of team word webbing iis effective in writing skill for the first semester students of Hamzanwadi University in the academic year 2017-2018 and examining how effective was team word webbing in teaching writing for the first semester students of Hamzanwadi university in the academic year 20172018. Pre-experimental design was applied for this research since it had experimental group only without control group. The sample of this study was 70 of 120 students. The data was collected through a pre-test and a post-test which were given to the EFL students.To analyze the data, the author applied SPSS 22 for Windows. After submitting the data to paired samples t-test, it was found that there was a significant difference in the mean scores between the pre-test and post-test, which was $t(\mathrm{df}=18)=10.550$ at $p=.000$ which lower than 0.05 as the standard significance level in SPSS at two tails. In short, team word webbing technique was significantly effective in writing skill for the EFL students. Having considered the process and the result of this study, the author suggested that English teachers use team word webbing in teaching writing in language learning because it helps student to express their ideas and can become more creative in teaching learning process especially in writing skill.
\end{abstract}

Keywords: team word webbing, writing skill

\section{Introduction}

Language refers to a system of sounds used by human for communicating, thinking and feeling. It plays role as a means of conveying the ideas, thoughts, opinions, and feelings. One lingua franca which is used all over the world is English. It is used as a means of communication in international forums, such as conferences, education, business, or global market, so it is urgent to face the globalization era. In countries which still consider English as a foreign language, English is not spoken or written widely, yet it is still taught as a compulsory subject from primary education to university level. Because English is mainly found in formal education, the teachers need to find solution to improve the students 'achievement in English. There are four skills which we should master, those are speaking, listening, writing, listening and reading. Listening and reading are called receptive skills, while writing and speaking are productive skills. In order to make this study clear and detail, the author limit to discuss the problems of writing skill only. Writing is a form of communication. It is an action of making marks on certain surface in a form of writing 
presentation to create meaning. Writing is the fourth skill in English language which needs process. Oshima and Hogue (1997, p.2) state that "writing takes study and practice to develop this skill. For both native speakers and beginners of English, it is important to note that writing is a process, not a product". Writing is a progressive activity. It means that when learners for the first time write something down, they have already been thinking about what they are going to say and how they are going to say it. Then after learners have finished writing, they read over what they have written and made changes and corrections. Therefore, writing is never a one-step action; as it is a process that has several steps. A lot of students said that writing is difficult skill, but it is actually easy and enjoyable activity if there is an appropriate method and interesting teaching technique. Nunan (1998, p.88) defined that "writing is the process of thinkingto invent ideas, thinking about how to express into good writing, andarranging the ideas into statement and paragraph clearly". It indicates that the learners are expected to explore the ideas and make them into goodparagraph. Besides, writing is both a physical and a mental act. It is the physical act of committing words or ideas to some medium, whether it isan object or a symbol or an email message.According to Hogue (1996, p.6), "good writing is more than justusing correct grammar; it is also thinking, planning, checking, and revising". Therefore, the writing process needs thinking, planning, good idea and good grammar to make a good writing.

Writing is an importantpart of language, because learners must realize that writing a language ismuch more difficult than speaking it. Lyons and Heasly (as cited in Nunan, 1998, p.91) stated that "writing is clearly a complex process and competent". Writing is frequently accepted as being the last skill acquired.Based on this statement, it can be concluded that writing is a complex process. Writing is a continuous activity that has more than one step but it needs steps. The most important in writing is process not a product. Brown (2001, p.335) stated that "written products are often the result of thinking, drafting, and revising procedures that require specialized skill, skill that not every speaker develops naturally. Writing needs thinking that focuses students on how to generate ideas. Written product involves thinking, drafting, and procedure. Skills are also important in writing activity. Based on the theories of writing, it can be concluded that writing is the process of thinking to invent ideas, thinking about how to express intogood writing, and arrange the ideas into statement and paragraph clearly. It indicates that the learners were expected to explore the ideas and make them into good paragraph. The indicator of writing skill in this research was exploring the ideas and making them into good descriptive paragraph. The scoring was based on indicators of writing competence, namely content, organization, vocabulary, language, and mechanics.

This is also supported by Fegerson and Mickerson (1992, p.7) who stated that "writing is a skill thatis acquired through study". Writing is one of English skills that should be taught integratively, but it is regarded as the most difficult language skill to learn for learners.

Then, the students have to consider aspects of writing such as grammar, mechanics, content, vocabulary, and organization when they write. Therefore, writing skill is not easy and complicated. There are certain genres of texts which should be learnt by the students namely narrative, recount, procedure, descriptive, report, news item and so forth. The focus discussion in the present research was recount text.Recount Text is text of recount tell a story about event or incident which have elapsed or is past, usually about experience of writer 
person. Writer could tell any kind of their experience which have passedwhether the experience mmiserable or please.Furthermore, writing in the students' opinion is boring and a lot of students are reluctant to write somethingwhen learning in the class. to solve the problems stated previously, technique and strategy are needed to apply. The main aim of technique and strategy is to achieve writing learning goal that is expressing meaning in functional writing text and essay. The technique applied in this study was team word webbing Team word webbing technique can ease the students to arrange the ideas for grammar and vocabulary easily. Jeanne M Stone (2007) argues that team word webbing is a tool in concept of development and information exchange. By applying it, the students are motivated to be creative because they are free to find and arrange their background knowledge which are related to the topic that they want to write.

Word webbing is a technique that can be used to expand idea or words. This technique is helpful for the students who want to expand idea or words, especially in learning vocabulary. From the keyword given, the students make their own words which is related to the keyword. Students first put an interesting topic in the centre circle of the map/web. The students brainstorm what words are related to the topic. Students draw line or branches from the topic and write every words related to the topic. Each line consists of one word that related to the topic and then draw a circle. Team word webbing technique makes students easy in learning writing and expand their idea.

By working simultaneously on a piece of paper, students write words which are important in the topic being studied and make drawings which illustrate the main topic and their supporting elements. Before implementing team word webbing, students should have numerous opportunities to web as a teacher direct the activity (Wiesendanger, 1992).

Word webbing technique can help the students to build the development of their ideas easily. Stone (2007) argues that "word webbing is a tool in the concept of developmnet and information exchange". By applying it, the students are motivated to be creative because they are free to create new ideas and put it on a piece of paper and become a writing product. Team word webbing also helps the students to be free to use their background knowledge which can be related with the topic that they want to write. Moreover, the students can write a list of words to the topic, then organize them in graphic, identify the relationship by drawing lines to represent the connections. By exploring the topic that they are familiar with, the students can be driven to develop some related vicabulary because this technique is more visual. The use of team word webbing teaching learning is to analyze the concepts into components, to understand multiple relations among ideas and to differentiate concepts.

Webbing works well for coming up with ideas or developing words quickly. The first stage of the webbing is deciding a topic and putting it in the center and make a circle around it. Next, write another word, make a circle again and draw a line between them. It is clear that webbing works easily. The stage of webbing is described as follow.

By using team word webbing technique, the students could develop their idea on the every steps of generic structure of text based on their knowledge. It can be explained that webbing shows the relationship among the words. From the keyword "my holiday", students can mention and write a lot of words which are related to the keyword and make a circle around it. The webbing is webbing with three levels. The first level is the word my journey 
with the other words around the word "my journey" (teak plantation), the second level is beach, and my expression with certain words around them (coconut trees, boat). Finally the third level is my impression with the words related to are tired and fun.

Word webbing is a proper terchnique to teach writing. In learning process, teacher will introduce the category of words or offer the topic, for example my holiday. Then, teacher suggests students to use the word category or topic as keyword and ask them to write the word in centre and circle that represent the keyword. Then student writes another word, circle again and draw a line between them from the keyword. Each line consists of one word that related to "my holiday" such as my journey, beach and my impression. By using this word webbing, students are hoped to find their own new words that related to keyword.

The followings are procedures to teach writing by using team word webbing tehnique. First, students are instructed to gather around and make a circle form, second, the teacher asks students to think about a topic. Many topics are mentioned by them and the teacher chooses one of them. For example "my best holiday. Third, after the teacher gets the students'respond. Ask them what they think about the best holiday. Fourth, the students mention everything about holiday include the location and detail of the holiday. This activity makes students think more and build their idea, fifth, teacher writes "cat" in center of board and then circle it. Sixth,teacher asks students to think more about "my best holiday", the student who answer is asked to write his word around the word "my best holiday" then circle it. Seventh,teacher asks another student to draw a line between the words on the board. After that teacher tells them that the line means teh relationship of the words. Eighth, teacher asks for more suggestion from the class until the students got enough ideas. Ninth, the next activity is the time for each student to make his/her own web maps. Finally to make them able to use this technique, the teacher just make an example of webbing with the levels.

Research on team word webbing has been conducted previuosly by Hermita (2017). The research purpose was to find out the increase of students' ability in reading comprehension that was taught by using team word webbing technique. It was quasi experimental method which was conducted in SMA Negeri 14 Makassar in academic year 2017/2018. The similarity was the technique, whereas the differences were the level of education and the skill. She applied team word webbing to increase reading comprehension which resulted in the significant improvement in the students' reading ability after being taught by team word webbing technique.

Based on the background of study above, the present researcher states two purposes of the study; to find out whether team word webbing was effective on writing recount text for the first semester of English study program at Hamzanwadi university in the academic year 2017-2018 and to know how effective was team word webbing in writing recount text for the first semester of English study program at Hamzanwadi university in the academic year 20172018.

\section{Method}

In this research, the author applied pre-experimental research. Here, the present researcher gives command and the students respond to these with physical actions. The test 
involves pre-test and post-test. The pre-test was given at the first time, and the post-test given after teaching and learning process was conducted.

\subsection{Participants}

The participants in the present study were the first semester of English study program at Hamzanwadi University. The total number of students was 120 but the author took 70 students as the research sample which derived from two classes. The number of sample was considered to be representative enough for the research.

\subsection{Data Collection}

\subsubsection{Instrument of Collecting Data}

In this research, the author uses written test as the instrument in which a command was written on a piece of paper distributed to the students to know their writing ability. The command in form of the topic was "please write a texton experiences about something which related to real life and learning in school." The test was proposed based on several conditions. The material of test must be usually like a make something in our live and suitable with grade of the study.

\subsubsection{Techniques for Collecting Data}

The data of this study was obtained by using a pre test and post test (face to face performance with the teacher and other students). The topic or the command of pre-test and post-test are in the same form such as the students are asked to tell about their past experience which related to their real life and learning at school to create recount text. In treatment, the author applied team word webbing technique to teach recount text. In order to get data, the author collected data as follows: 1) the present researcher use the recount text to collect the data. 2) order students to write it the practice of achievement.

\subsection{Data Analysis}

The data of this study was analyzed by using descriptive statistics. It was used to know the mean and the standard deviation of students' scores in writing test. Before analyzing the hypothesis testing, the reseracher first analyzed normality and homogeneity of the data. The result of analysis shoewd that the values of analysis were more that .05 , it mean that the data were normal and homogen. Then, To know the effective of team word webbing in teaching writing of recount text, the present researcher used SPSS Statistics 22 for Windows. As the output, the SPSS statistics show the result of the procedure which indicated that the hypothesis was accepted or rejected.

\section{Findings}

Based on the gained data in pre-test before the researcher offered a treatment it was found that the mean score was 39.16, and the standard deviation was 10.715. Meanwhile, when the present researcher gives a treatment and in posttest it was obtained that the mean score was 47.37, and the standard deviation was 10.771 . 
Table 1. Students' mean scores on pretest and posttest

\begin{tabular}{lll}
\hline $\mathrm{N}$ & Pre test & Post test \\
\hline Mean score & 39.16 & 47.37 \\
Standar deviation & 10.715 & 10.771 \\
\hline
\end{tabular}

After finding the result of normality testing the next activity was calculating the hypothesis testing. Referring to the result of hypothesis testing the researcher used a paired sample t-test, it was found out that mean score between pre-test and post-test, the $t$ test was $t$ $(\mathrm{df}=18)=10.550$ at $p=.000$ which lower than 0.05 as the standard significance level in SPSS at two tails. Thus, the Alternative Hypothesis (Ha) was accepted and the Null Hypothesis (Ho) was rejected. Meaning that team word webbing technique was significantly effective on students' ability in writing recount text for the first semester students of English study program at Hamzanwadi University.

\section{Discussion}

The purposes of this research were to find out whether team word webbing was effective on writing recount text for the first semester of English study program at Hamzanwadi university and to know how effective was team word webbing in writing recount text for the first semester of English study program at Hamzanwadi university in the academic year 20172018.

Word webbing technique could motivate the students to think deeper about the ideas which will be written in each paragraph, construct complete sentences with correct grammar, remove unimportant words and arrange proper generic structure based on the based on the key words given inside every circle, which could make the students interested in producing a text. It was found that when the research was conducted for the first time, the students still have low ability to arrange ideas into appropriate paragraph. Then, the reseracher applied word webbing technique during teaching and learning process along with contextual teaching learning which intended to bring actual life into the classroom to create relax feeling for the students.

Furthermore, word webbing technique was interesting because it offers chance for students to be creative in arranging proper generic structure with smooth flowing ideas. During the early treatments, some students seemed less effort to develop ideas and accomplish their writing texts since they tended to lack knowledge on mechanics, vocabulary, grammar. After the teacher had motivated and encouraged with the process of creating good text by putting the key words of each paragraph in circles first and then teaching them to arrange the paragraph into correct organization of generic structure, so they are not left behind the students who have mastered writing. The results of this research supported the previous research which was conducted by Hermita (2017) which showed that team word webbing technique improved students' ability in English. This finding also fit with Stone's (2007) idea that "word webbing is a tool in the concept of developmnet and information exchange". By applying it, the students are motivated to be creative because they are free to create new ideas 
and put it on a piece of paper and become a writing product. It can be concluded that team wed webbing technique was significantly effective on students' achievement of writing recount text for first semester students of English study program at Hamzanwadi University.

\section{Conclusions}

Based on the result of the study, the present researcher concludes that team word webbing was significantly efefctive because the value of post-test was higher than pre-test which meant that the standard deviation and mean score were significant. It was concluded that the students' ability after treatment were better than before. Having processed the data, the researcher concluded that team word webbing technique was effective on students' writing recount text for the first semester students at Hamzanwadi Universityin the academic year There was a significant difference in the mean scores between pre-test and post-test. The result of testing hypothesis proved that the alternative hypothesis (Ha) was accepted and the null hypothesis (Ho) was rejected. It means that Contextual Teaching and Learning is significantly effective on students 'ability in writing recount text for the first semester at Hamzanwadi Universityin the academic year 2017-2018.

\section{References}

Brown, H. Douglas. (2001). Teaching by principle: An imperative approach to language pedagogy, 2nd Ed. New York: Addison Wesley Longman, Inc.

Bryman, Alan. (1989). Research methods and organization studies. London and New York: Routledge is an imprint of the Taylor \& Francis Group.

Fegerson, Laraine and Mickerson, Marie-Louse. (1992). All in one. New Jersey: Marie- Louse Prentice Hall.

Harmer, Jeremy.(1991). The practice of English language teaching. London: Longman .

Hiebert, Alfrieda H.,\& Kamil, Michael L. (2005). Teaching and learning vocabulary. London: Mawah.

Hogue, C.C. (1996). Disablement models in nursing research: Opportunities and potential pitfalls. New York: Addison Wesley Longman.

Hornby. (1998). Oxford advanced learner's dictionary of current English. New York: Oxford university press.

Mazidatur Rohmah, Laily. (2012). The effect of using webbing technique on grade-8 students' reading comprehension achievementat SMP NEGERI 5 Tanggul Jember. Jember University. East Java. Indonesia.

Moedjito. (2016). Basic statistics for research in language education. Unpublished book. Nusa tenggara barat. Indonesia.

M. Stone, Jeanne. (2007). Cooperative Learning Reading Activities. Australia: Hawker Brownlow Education.

Nunan, David. (1998). Designing task for the communicative classroom. Cambridge: Cambridge University Press. 
Wiesendanger, Katherine D. And Louis Bader. (1992). Reading horizons. Michigan: Michigan State University.

Oshima, Alice,\& Ann Hogue. (1997). Introduction to academic writing. New York: Addison Wesley Longman

Suharsimi. (1998). Prosedur penelitian: Suatu pendekatan praktek. Jakarta:Rineka Cipta.

Syahril.( 2014). The effectiveness of Grouping words technique to enhance students' basic vocabulary at the first year students MTs Madani Alauddin Paopao. Published thesis. Tarbiyah and Teaching Science Faculty of UIN Alauddin. Makassar. Indonesia.

Ur, Penny. (1996). A course in language teaching: Cambridge : Cambridge university press. 